\title{
Tumor Necrosis Factor-induced Reversal of Adipocytic Phenotype of 3T3-L1 cells Is Preceded by a Loss of Nuclear CCAAT/Enhancer Binding Protein (C/EBP)
}

David Ron, Allan R. Brasier, Robert E. McGehee, Jr., and Joel F. Habener

Laboratory of Molecular Endocrinology, Massachusetts General Hospital, Howard Hughes Medical Institute, Harvard Medical School, Boston, Massachusetts 02114

\begin{abstract}
Tumor necrosis factor (TNF)-treated 3T3-L1 adipocytes were used as a model for studying the effects of systemic inflammation on adipose tissue. Lipopolysaccharide-treated monocyteconditioned medium or recombinant human TNF $\alpha$ induced morphological dedifferentiation of the adipocytes and led to loss of adipocyte specific gene expression. Gel shift, Southwestern and Western immunoblot analysis demonstrated that dedifferentiation was preceded by a decrease in the DNA binding activity and protein level of the transcription factor CCAAT/enhancer binding protein (C/EBP). Liver activating protein, a related protein that binds identical DNA sequences, increased during cytokine treatment. Both proteins activate specific enhancer elements located in the promoter region of many genes whose transcription is altered during systemic inflammation. Pulsechase labeling followed by immunoprecipitation demonstrated that $\mathrm{C} / \mathrm{EBP}$ is a rapidly turning over protein in adipocytes and that cytokine treatment led to a specific, time dependent decrease in its rate of synthesis. Because C/EBP binding sites have been shown to play an important role in regulating the expression of genes involved in adipocyte metabolism, we propose that the TNF-induced changes in the complement of transcription factors binding those sites may be important in the pathogenesis of inflammation-induced atrophy of adipose tissue. (J. Clin. Invest. 1992. 89:223-233.) Key words: acute phase $\bullet$ adipocytes $\bullet$ cytokines $\bullet$ cachexia
\end{abstract}

\section{Introduction}

Weight loss associated with atrophy of adipose tissue is commonly encountered in human disease. This occurrence and the associated weakness and lassitude, referred to as the syndrome of cachexia, often contributes directly to the morbidity associated with chronic illness. The syndrome develops to varying degrees in many patients in advanced stages of illness (1). Tu-

This work was presented in abstract form at the 1991 Endocrine Society Meeting, Washington, DC.

Dr. Brasier's current address is University of Texas Medical Branch at Galveston, Division of Endocrinology and Hypertension, Medical Research Building Room 321, Galveston, TX 77550. Address correspondence to David Ron, M.D., Laboratory of Molecular Endocrinology, Massachusetts General Hospital, Howard Hughes Medical Institute, Harvard Medical School, Boston, MA 02114.

Received for publication 22 July 1991 and in revised form 11 September 1991 .

J. Clin. Invest.

(c) The American Society for Clinical Investigation, Inc.

$0021-9738 / 92 / 01 / 0223 / 11 \$ 2.00$

Volume 89, January 1992, 223-233 mor necrosis factor (TNF), ${ }^{1}$ a $17-\mathrm{kD}$ cytokine secreted from activated macrophages, has been postulated to play a role in the pathogenesis of cachexia. Originally identified as cachectin, TNF has been shown to be a mediator of profound inanition accompanying chronic protozoal infection in rabbits (2). Subsequent correlative clinical studies have demonstrated elevated levels of TNF in the serum of patients with chronic bacterial infections (3), parasitic infections (4), cancer (5), AIDS (6), and severe chronic heart failure (7). Sustained elevation of serum TNF levels in experimental animals leads to profound weight loss associated with atrophy of all visible body fat, giving rise to a syndrome similar to human cachexia (8).

TNF causes a dramatic morphological dedifferentiation of adipocytes in culture (9). Treatment of adipocytes with TNF is associated with a decrease in the activities and rates of synthesis of key adipogenic enzymes $(10,11)$. This later event is, in turn, associated with a repression of the transcription of a subset of adipocyte specific genes $(9,12)$. It thus appears that the actions of TNF on cultured adipocytic cells can serve as a cell culture model for some of the important biochemical events associated with the development of human cachexia.

CCAAT/enhancer binding protein (C/EBP) is a transcription factor enriched in liver and adipose tissue, that binds and activates cis-acting regulatory elements in the promoter regions of many genes that are expressed at high levels in adipose tissue (13-16). A feature common to many of the genes activated by $\mathrm{C} / \mathrm{EBP}$ is an apparent role for the gene products in the regulation of intermediary metabolism in adipose tissue and liver (17). Angiotensinogen mRNA is also induced during the differentiation of 3T3-L1 fibroblasts into adipocytes (18) and this induction coincides with the accumulation of C/EBP DNAbinding activity in the cell nuclei (McGehee, R. E., Jr., et al., unpublished observations). The link between C/EBP and expression of the adipocytic phenotype is further strengthened by the fact that C/EBP is induced to high levels during the terminal differentiation of 3T3-L1 cells into adipocytes; C/EBP protein is undetectable in fibroblastic $3 T 3$ cells $(14,19)$. Recently, other DNA-binding proteins have been identified that are capable of binding the same DNA sequences that bind C/EBP. One such transcription factor, liver activating protein (LAP, 20), appears to account for much of the C/EBP site-specific DNAbinding activity present in nuclei that is not attributable to C/EBP itself. Identical or homologous cDNA's have been identified by several other groups and the encoded proteins are referred to as NFIL-6 (21), IL-6DBP (22), and AGP/EBP (23). LAP and C/EBP bind promoter elements involved in cytokine-

1. Abbreviations used in this paper: APRE, acute phase response element; C/EBP, CCAAT/enhancer binding protein; CRE, cyclic AMP response element; CREB, CRE binding protein; EMSA, electrophoretic mobility shift assay; $L A P$, liver activating protein; $N F_{\kappa} B$, nuclear factor kappa B; TNF, tumor necrosis factor. 
induced transcriptional regulation of the activity of several acute phase responsive genes, suggesting a role for these factors in mediating cytokine-induced changes in the expression of these genes.

Our studies on the regulation of the angiotensinogen gene in liver during the acute phase response led to the identification of a hormonally induced enhancer unit consisting of two glucocorticoid responsive elements and a cytokine responsive 28-bp palindromic sequence termed the acute phase responsive element (APRE, 24-26). The APRE binds, in a mutually exclusive manner, members of either of two classes of transcription factors: the interleukin-1 (IL-1) and TNF-inducible nuclear factor kappa $\mathrm{B}(\mathrm{NF} \kappa \mathrm{B})$ or a heterogeneous family of C/EBPlike proteins (27). In the course of these studies we made the observation that induction of the acute phase is associated with a decrease in the level of C/EBP in rat liver nuclei (Ron, D., et al., unpublished observations).

The acute phase response, induced by lipopolysaccharide injection into rats, is associated with elevated levels of circulating TNF (10). Because of the possibility that C/EBP and LAP play a role in regulating the transcriptional activities of genes involved in adipocyte metabolism, and because conditions associated with elevation of TNF are also associated with a repression of adipocyte metabolism, we sought to determine whether an in vitro model for the acute phase is associated with a change in the level of C/EBP and LAP in adipocyte nuclei.

\section{Methods}

Bacterial expression of LAP and $C / E B P$ and DNasel footprinting of the angiotensinogen promoter. Bacterial expression plasmids encoding the DNA-binding domains of LAP and C/EBP were constructed by amplifying, in the polymerase chain reaction (PCR), a fragment of cDNA encoding amino acid residues 211-297 (21) and residues 271-359 (28), respectively. C/EBP was amplified, using as a target, a plasmid containing the rat cDNA (gift of S. McKnight). LAP was amplified from HepG2 cell cDNA and therefore encodes the DNA-binding domain of its human homologue, NFIL-6 (the amino acid sequences of the two homologues, in the amplified region, are virtually identical). The PCR primers were constructed to incorporate a convenient Ncol site at the $5^{\prime}$ end of the amplified sequence which encodes an in-frame initiator methionine and allows directional ligation of the cDNA into the bacterial expression vector pET 8c (29). Sequence of the C/EBP primers: 5'GGC GGG GCC GCC ATG GGC AAG GCC AAG AAG 3' and 5 GGA TCC TCA CGC GCA GTT GCC CAT TGC CTT GAC 3'; sequence of the NFIL-6 primers: 5' GCG CCC TCC ATG GTC AAG AGC AAG GCC AAG AAG ACC GTG G 3' and 5' GCG GGG GAT CCT CGA GCA GTG GCC GGA GGA GGC GAG CAG G 3'. The recombinant proteins were expressed in the $\mathrm{pLysS}$ lysogenized strain of Escherichia coli BL21, DE.3. Crude bacterial suspensions were lysed by sonication, and heated to $65^{\circ} \mathrm{C}$ for $10 \mathrm{~min}$. The heat stable recombinant proteins were recovered in the supernatant of the lysate. DNaseI footprinting was performed as described previously (30). As little as 0.5 $\mu \mathrm{l}$ of the bacterial lysate, containing $50 \mathrm{ng}$ of recombinant protein, produces a clear DNaseI protected region over the APRE. A full length bacterial expression vector for $\mathrm{C} / \mathrm{EBP}$ was constructed by ligating the Ncol fragment of the rat C/EBP cDNA into the Ncol site of a pET8c plasmid that had an inserted oligonucleotide encoding the four carboxy-terminal amino acids of C/EBP followed by a stop codon. The LAP expression vector was a gift of Ueli Schibler and Patrick Descombes (20).

Analysis of nuclear proteins from cytokine-treated adipocytes. 3T3$\mathrm{L} 1$ fibroblasts were induced to differentiate to adipocytes as described previously (31). At various times before harvest (on day seven of the differentiation protocol), $0.5 \% \mathrm{vol} / \mathrm{vol}$ of conditioned medium pre- pared from LPS-treated raw 264.7 monocytic cells (2) was added to the culture medium. Nuclear extracts were prepared from the cells (32). Electrophoretic mobility shift assays (EMSA) were performed using 7 $\mu \mathrm{g}$ of nuclear protein (30). The DNA probe consisted of the APRE point mutant $\mathrm{M} 6$, a sequence that binds the C/EBP-like proteins with an affinity indistinguishable from wild type, yet fails to bind $\mathrm{NF}_{\kappa} \mathrm{B}(27)$. Bound complexes and free probe were resolved on a $6 \%$ nondenaturing polyacrylamide gel. In the antibody supershift experiments $1 \mu \mathrm{l}$ of antisera or control nonimmune antisera was added to the nuclear extract and incubated at room temperature for $20 \mathrm{~min}$ before the EMSA. For analysis of $\mathrm{NF}_{\kappa} \mathrm{B}$ DNA-binding in EMSA $\kappa \mathrm{BE}$ probe was used (27). For analysis of cytokine induced changes in the activity of a C/EBP binding site-containing promoter, pools of stably transfected 3T3-L1 cells ( $>30$ pools per experiment) containing the reporter plasmid [M6]X4p59rATLUC (27) were induced to differentiate and after attainment of the adipocytic phenotype were treated with $0.5 \% \mathrm{vol} / \mathrm{vol}$ monocyte-conditioned medium for the indicated period of time. Cytosol obtained in the course of preparation of nuclear extracts were assayed directly for luciferase activity (30). The control plasmid, [Col8]x3p59rATLUC, contained a cyclic AMP response element binding protein (CREB)-binding site oligonucleotide (33) in place of the M6 oligonucleotide. Results are reported as means \pm range for experiments performed in duplicate.

Southwestern and Western immunoblots. 80- $\mu \mathrm{g}$ aliquots of nuclear protein were fractionated by $11 \%$ SDS-PAGE and electroblotted onto a nitrocellulose filter. For Southwestern blot the filter was denatured in 6 $\mathrm{M}$ guanidine hydrochloride (Gd-HCl) in TNE-50 (TNE-50: $20 \mathrm{mM}$ Tris pH 7.5, $50 \mathrm{mM} \mathrm{NaCl}, 1 \mathrm{mM}$ EDTA, $1 \mathrm{mM}$ dithiothrietol), renatured by four successive twofold dilutions in TNE-50, washed free of $\mathrm{Gd}-\mathrm{HCl}$, blocked in $10 \% \mathrm{wt} / \mathrm{vol}$ nonfat dry milk in TNE-50 and reacted with ${ }^{32} \mathrm{P}$-labeled APRE M6 probe $\left(0.5 \times 10^{6} \mathrm{cpm} / \mathrm{ml}\right.$ at $2 \times 10^{6}$ $\mathrm{cpm} / \mathrm{pM}$ ) in TNE-50 that contained $10 \mu \mathrm{g} / \mathrm{ml}$ poly dldC as a nonspecific competitor. For Western immunoblot analysis, the nitrocellulose filter was denatured in $6 \mathrm{M} \mathrm{Gd}-\mathrm{HCl}$, washed free of the salt in PBS that contained $0.2 \%$ Tween-20, blocked in the same solution containing $10 \%$ nonfat dry milk, and reacted with the specific rabbit polyclonal antiserum. C/EBP was detected with a 1:200 dilution of the previously described alpha-14 antipeptide antisera (gift of S. McKnight [28]). LAP was detected by a 1:3,000 dilution of the anti-IL-6DBP antisera raised against the bacterially expressed recombinant protein (a gift of R. Cortese and D. Ramji [22]). CREB was detected by a 1:10,000 dilution of the R1090 antisera directed against the sequence containing the phosphorylation box (34). The bound primary antibody was visualized by enhanced chemoluminescent detection (ECL kit; Amersham Corp., Arlington Heights, IL) of secondarily bound horseradish peroxidaseconjugated goat anti-rabbit IgG (Bio-Rad Laboratories, Richmond, CA). For the LAP supershifts an antibody directed against a peptide corresponding to amino acids 54-70 was used. Specificity of the antisera and lack of cross-reactivity of the anti-C/EBP antiserum with LAP and anti-LAP antiserum with C/EBP was documented in an antibody supershift EMSA and in Western blots using bacterially expressed C/ EBP and LAP (data not shown). Immunohistochemical staining of $\mathrm{C} / \mathrm{EBP}$ was performed on the fully differentiated adipocytes exactly as described, using the anti-alpha-14 antiserum (35).

For analyses of the effects of various cytokines on levels of nuclear C/EBP, bacterially expressed recombinant cytokines were obtained from the following sources: Human IL-6 and TNF- $\alpha$ from Bachem, Torrance, CA; human IL- $1 \alpha$ was a kind gift of S. Gillis, Immunex Corp., Seattle, WA.

Immunoprecipitation of ${ }^{35} \mathrm{~S}$-labeled C/EBP was performed essentially as described (36). 3T3-L1 adipocytes were cultured in $60-\mathrm{mm}$ plates, ${ }^{35} \mathrm{~S}$-methionine/cysteine (Translabel; ICN Pharmaceuticals, Inc., Irvine, $\mathrm{CA})$ was added $(800 \mu \mathrm{Ci} / \mathrm{ml})$ to serum-free medium for 1.5 $h$ followed by a variable length of cold chase. Nuclei were isolated and lysed in RIPA (Tris-buffered saline $0.5 \%$ deoxycholate, $1 \%$ Triton $\mathrm{X}-100,0.1 \%$ lauryl sulfate) buffer. The lysate, in a volume of $500 \mu \mathrm{l}$, was reacted for $1 \mathrm{~h}$ at $4^{\circ} \mathrm{C}$ with anti-C/EBP alpha 14 antiserum. The immune complexes were precipitated with Staphylococcus aureus pro- 
tein A bound to agarose beads. After three washes of the precipitates in RIPA buffer, the labeled proteins were resolved by $11 \%$ SDS-PAGE and visualized by autoradiography. Similar immunoprecipitation experiments were performed on whole cell extracts and gave identical results with respect to the C/EBP signal, though background bands were more abundant.

For analyses of mRNAs, 20- $\mu \mathrm{g}$ aliquots of total cellular RNA from adipocytes were resolved on $1.2 \%$ agarose gels, transferred to nylon membranes, and analyzed by hybridization in a solution containing $50 \%$ formamide at $42^{\circ} \mathrm{C}$, to random prime labeled fragments of cDNA. The 1.1-kb Ncol fragment of C/EBP and the 0.15-kb Pst-EcoRI fragment of NFIL- 6 cDNA containing vector p 610 (the human homologue of LAP, a gift of S. Akira [21]) were used as probes for detection of $\mathrm{C} / \mathrm{EBP}$ and LAP, respectively. Actin and angiotensinogen mRNAs were detected as previously described (24). For detection of adipsin mRNA, the adipsin cDNA probe was amplified by the polymerase chain reaction from an adipocyte cDNA library. The amplified adipsin cDNA was body labeled and used as a probe.

Nuclear run-on analysis of control and 4-h conditioned-media- treated adipocytes were performed exactly as described (37). As hybridization targets for the in vitro labeled transcripts, the above mentioned C/EBP and LAP plasmids were used. pGEM3 plasmid DNA (Promega Biotec, Madison, WI) was included as a control for nonspecific binding.

\section{Results}

Monocyte-conditioned medium leads to dedifferentiation of adipocytic cells in culture. 3T3-L1 cells were grown to confluence and differentiated into adipocytes. Seven days after initiation of the differentiation protocol, $>90 \%$ of the cells had an adipocytic morphology with abundant cytoplasmic lipid. Upon treatment with $0.5 \%$ (vol/vol) monocyte-conditioned medium, a source rich in TNF (2), the cells underwent a profound morphological change; cytoplasmic lipid depletion was noted by 24 hours of treatment and was nearly complete at 48 hours (Fig. $1 \mathrm{a}$ ). The culture media, which is typically viscous

a

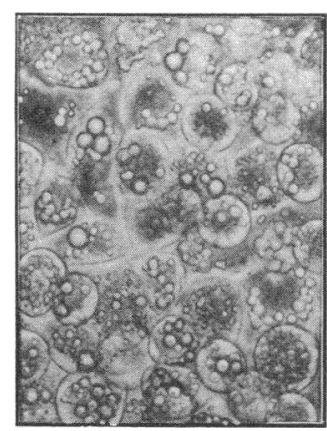

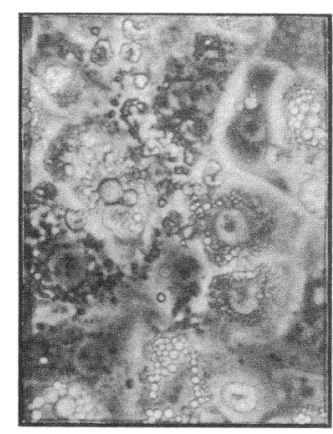

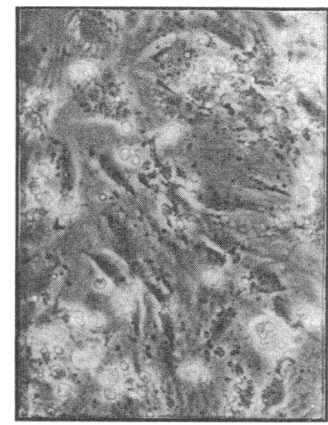

\section{Conditioned Medium: Untreated $24 \mathrm{hr}$. $48 \mathrm{hr}$.}

\section{b}

Conditioned
Medium, hours:
03

6

\section{ANGIOTENSINOGEN}

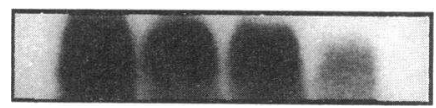

\section{ADIPSIN}

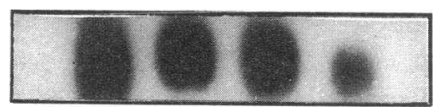

\section{ACTIN}

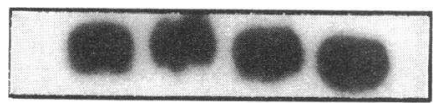

Figure 1. Effect of monocyte-conditioned media on adipocyte morphology and adipose-specific gene expression. $(A)$ Identically differentiated plates of 3T3-L1 adipocytes were treated with $0.5 \%$ vol/vol RAW 264.7 monocytic cell-conditioned medium for $48 \mathrm{~h}, 24 \mathrm{~h}$, or left untreated. The photomicrograph of a typical field of unfixed cells demonstrates the morphological changes induced by cytokine treatment: loss of lipid and reversion to a fibroblastic morphology. (B) Northern blot analysis of $20 \mu \mathrm{g}$ RNA isolated from conditioned medium-treated cells. The Northern blot was probed with a murine adipsin cDNA, rat angiotensinogen cDNA, and reprobed with an actin sequence oligonucleotide. 
BINDING OF C/EBP AND LAP TO THE ANGIOTENSINOGEN

APRE: Footprinting Assay

a

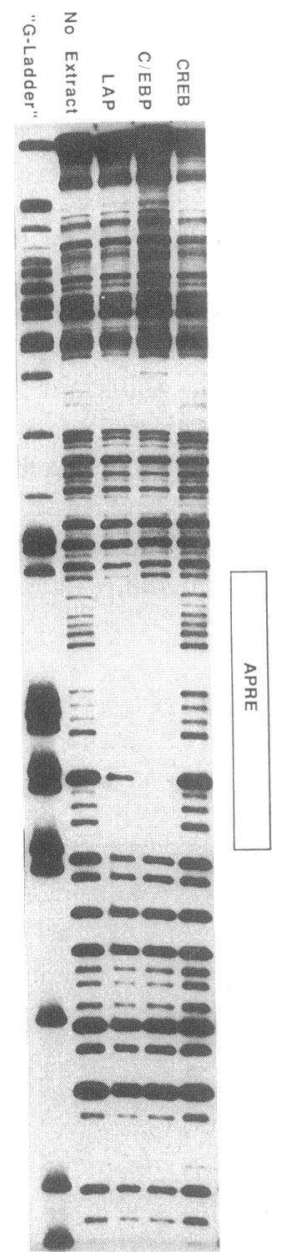

b

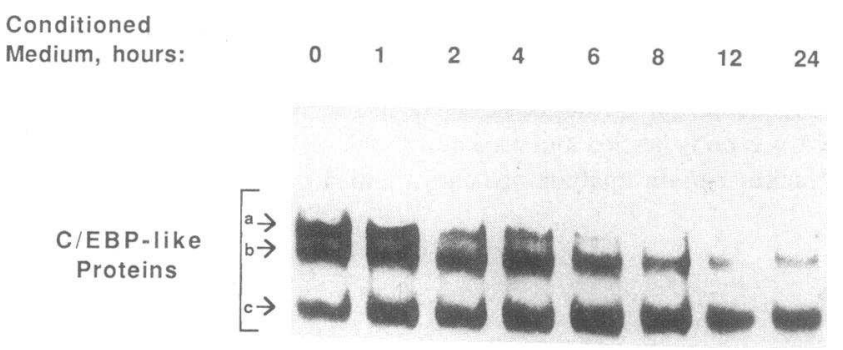

APRE

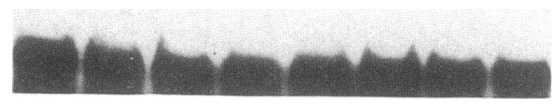

NFkB

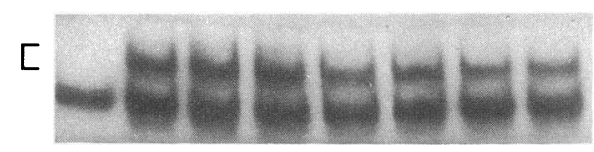

Figure 2. Cytokine-induced alterations in C/EBP-like DNA binding activity in 3T3-L1 adipocytes. (a) Identical binding of C/EBP and LAP to the acute-phase response element. The APRE-containing rat angiotensinogen gene promoter fragment (nt -615 to nt -526 ) was end labeled on the noncoding strand and subjected to DNasel digestion in either the absence of protein (no extract), or in the presence of bacterially expressed LAP $(L A P), \mathrm{C} / \mathrm{EBP}(C / E B P)$, or, as a negative control, CREB (CREB). End-labeled DNA fragments were resolved on a 9\% polyacrylamide, $7 \mathrm{M}$ urea gel. The position of the C/EBP-binding site $(A P R E)$ is indicated by the box to the right of the autoradiograph. (b) C/EBP-like DNA-binding proteins in adipocytes. 3T3-L1 cells were induced to differentiate into adipocytes. Inflammatory cytokines, in the form of lipopolysaccharidetreated raw 264.7 monocytic cell-conditioned medium, were added to the culture medium to a final concentration of $0.5 \%$ vol/vol. After the indicated time period, nuclear extracts were obtained. (Upper panel) The content of C/EBP-like DNA-binding activity in the nuclear extract was assayed by EMSA using labeled APRE M6 as a probe. The position of the different protein-DNA complexes is indicated to the left of the autoradiograph. (Lower panel) Identically performed EMSA using the NF $\kappa$ B-binding $\kappa \mathrm{BE}$ DNA fragment as a probe (the panel displays only the protein-DNA complex). The position of the cytokine-induced NFKB is indicated. (c) Contribution of C/EBP and LAP immunoreactive protein to the DNA-binding activity. Antibody supershifts of the protein DNA complex by specific antisera. $(d)$ Reporter gene activity of stably transfected cytokine-treated 3T3-L1 adipocytes. Luciferase activity directed by the C/EBP-binding site containing reporter gene normalized to protein content in conditioned media treated adipocytes.

(due to the secretion of matrix proteins from the differentiated cells) lost its viscosity, presumably due to the secretion of cytokine induced metallo-proteases.

These morphological changes were associated with a decrease in the levels of cytosolic mRNA encoding the representative adipocyte-specific genes: adipsin (38) and angiotensinogen (18). Actin mRNA levels in the same sample were unaffected by cytokine treatment (Fig. $1 \mathrm{~b}$ ). Similar changes were noted when recombinant human TNF $\alpha$ expressed in $E$. coli was used (data not shown). These experiments serve to demonstrate that cytokines secreted from activated monocytes can effect a rapid dedifferentiation of 3T3-L1 cells in culture. Similar results have been reported previously in a different murine adipogenic cell line, TA1 (9).

Cytokine-induced dedifferentiation of 3T3-L1 adipocytes is associated with a change in the pattern of C/EBP-like DNAbinding proteins. C/EBP shares with several other structurally related proteins an ability to bind the rat angiotensinogen gene acute phase responsive element (27). The ability of recombinant C/EBP and LAP, another dominant member of the $C$ / EBP-like family (20), to bind the angiotensinogen promoter is demonstrated in Fig. $2 a$ : both proteins give rise to an indistinguishable DNaseI protected footprint over the angiotensinogen gene APRE. Competition in binding demonstrates that both 


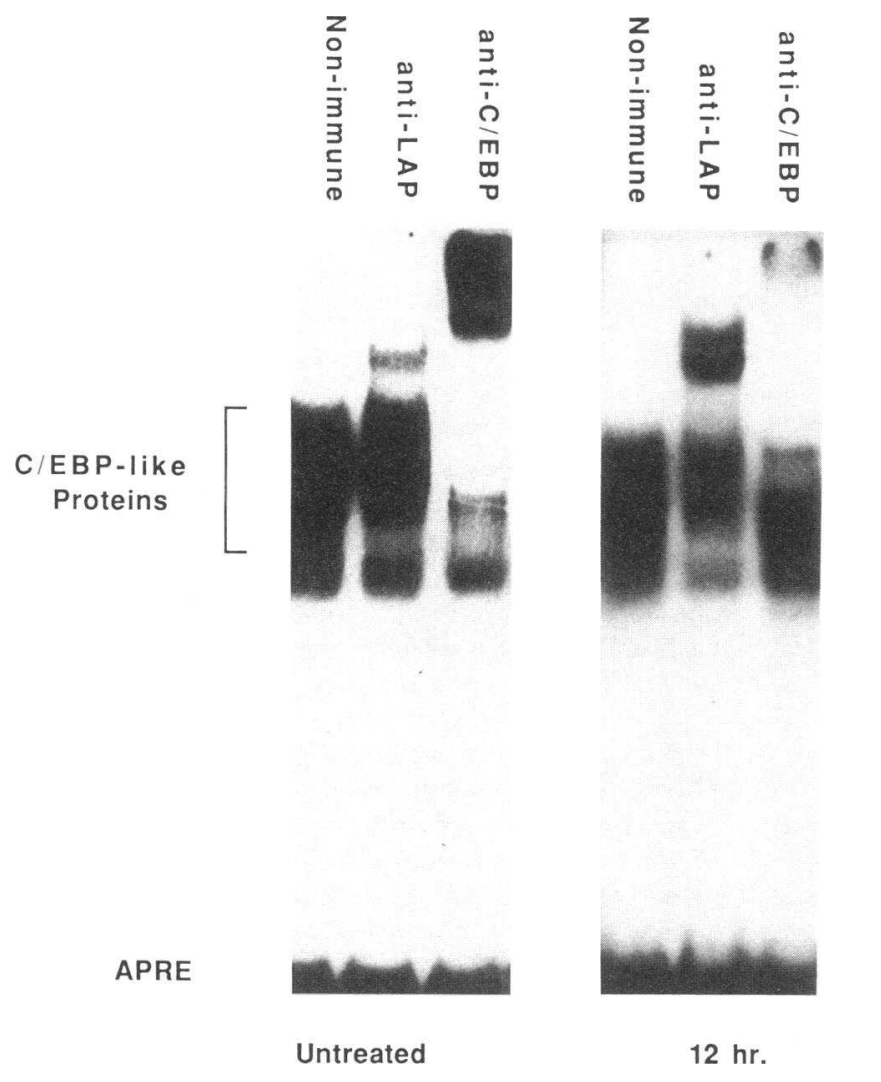

d

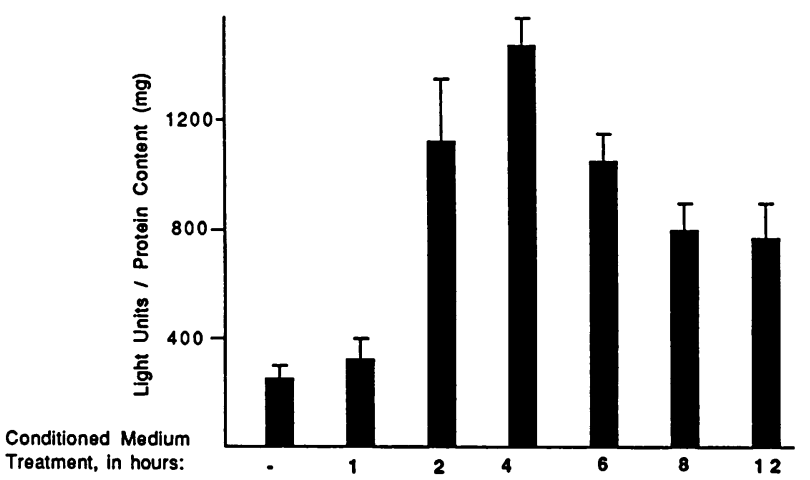

Figure 2 (Continued)

proteins bind the APRE with similar affinities (data not shown).

An oligonucleotide corresponding in sequence to the region covered by the C/EBP footprint (the APRE) was used as a probe in an electrophoretic mobility shift assay to detect $\mathrm{C}$ / EBP-like proteins in adipocyte nuclei. Treatment of the cultured adipocytes with $0.5 \%$ monocyte-conditioned medium led to a rapid alteration in the pattern of C/EBP-like DNAbinding proteins. The lower mobility complexes were reduced by such treatment and the faster mobility ones were induced (Fig. $2 b$ ). The C/EBP-like nature of the binding proteins detected by EMSA is suggested by their heat stability (all extracts were heated to $65^{\circ} \mathrm{C}$ for $5 \mathrm{~min}$ ), by the ability of anti-C/EBP and anti-LAP antisera to supershift a significant portion of the binding complex (Fig. $2 c$ ), and by sequence specific competition with unrelated oligonucleotides (data not shown). The rapidity of the response to cytokines is demonstrated by a comparison of the changes that occur in the C/EBP-like proteins with those that occur in the posttranscriptionally modified $\mathrm{NF}_{K} \mathrm{~B}$ in the same nuclear extracts (Fig. $2 b$, lower panel).

The antisera supershift experiments directly demonstrate the participation of C/EBP and LAP in the APRE-binding complex. Before cytokine treatment the majority of the DNAbinding activity is reactive with the anti-C/EBP serum, whereas after cytokine treatment the anti-LAP serum supershifts the majority of the probe (Fig. $2 c$ ). From these studies we conclude that treatment of adipocytes with monocyte-conditioned me- dium, leads to a reduction in C/EBP DNA-binding activity and an increase in LAP DNA-binding activity.

To evaluate the functional consequences of the cytokineinduced changes in C/EBP-like proteins, in terms of the activity of a promoter that binds these proteins, we made use of pools of 3T3-L1 cells stably transfected with a luciferase reporter gene drive by four copies of the angiotensinogen gene C/EBP-binding site, the M6 oligonucleotide (27). After differentiation into adipocytes, the cells were treated with $0.5 \%$ monocyte-conditioned medium and luciferase activity was measured in the cytosol. Cytokine treatment led to a rapid and transient increase in reporter gene activity, with a maximal fivefold increase measured within four hours (Fig. $2 d$ ). This induction is specific to the C/EBP-binding site containing promoter because no increase in reporter gene activity was seen when control adipocytes transfected with an identically constructed cyclic AMP responsive element (CRE)-containing promoter were used (data not shown).

Cytokine-induced dedifferentiation of adipocytes leads to a reversal of the differentiation-induced profile of $C / E B P$ and $L A P$. 3T3-L1 cells were induced to differentiate to adipocytes. After differentiation the cells were treated with $0.5 \%$ monocyte-conditioned medium. Nuclear extracts were prepared at several points in the course of the differentiation process and after cytokine treatment of the differentiated cells. The proteins in the extract were resolved by PAGE-SDS, blotted onto a nitrocellulose filter, and the blot was reacted with labeled 

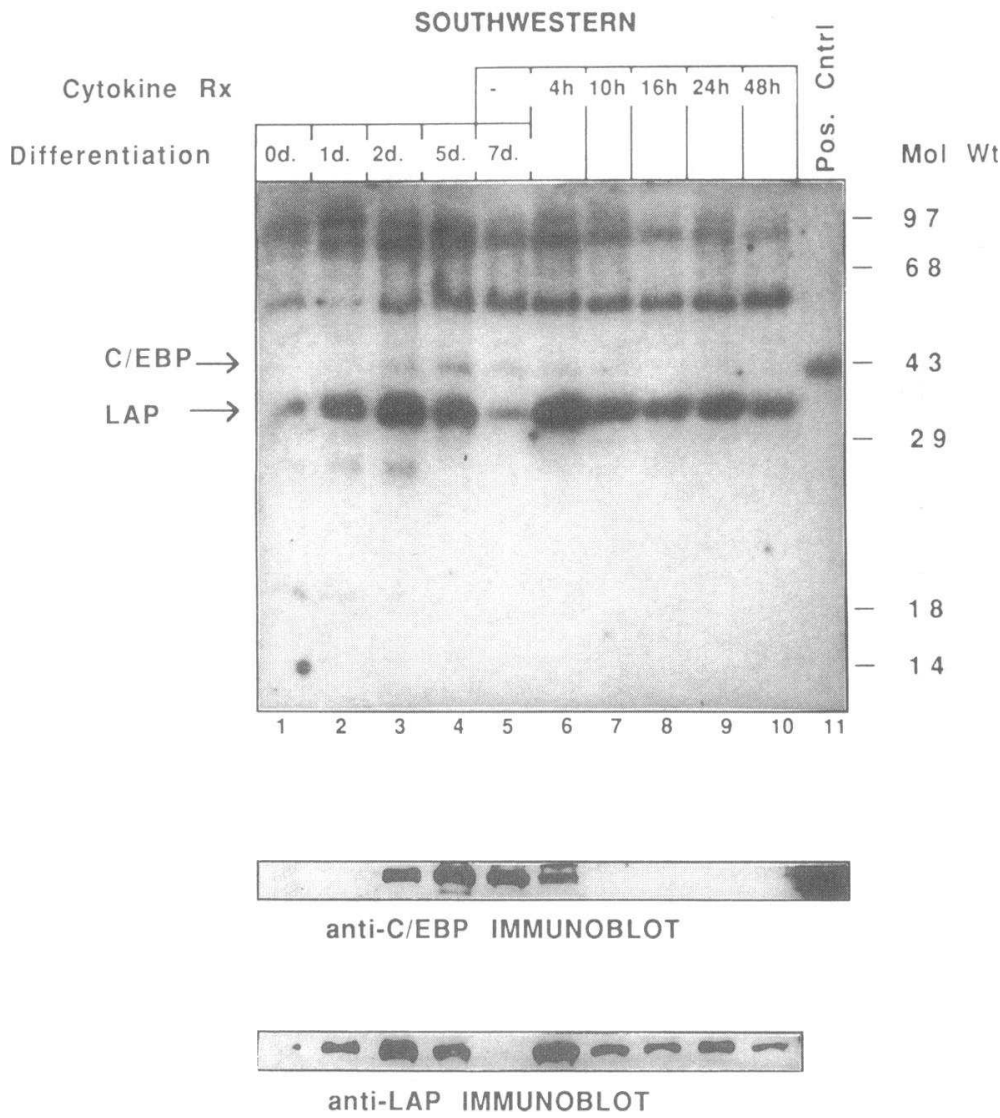

anti-LAP IMMUNOBLOT

APRE oligonucleotide (Southwestern blot). Differentiation to the adipocytic phenotype was associated with the transient induction of a prominent 36-kD DNA-binding protein. This activity peaked on day five of the differentiation process only to fall by day seven, by which time the cells had attained a fully differentiated phenotype (Fig. 3, top panel, lanes 1-5). A more faint 42-kD DNA-binding protein was also induced by differentiation: its levels peaked by day five but remained elevated on day seven. Cytokine treatment of the cells led to a reversal of the differentiation-induced changes in the level of these two proteins: the $36-\mathrm{kD}$ protein increased in abundance and the $42-\mathrm{kD}$ protein decreased. Cytokine treatment was carried out between the sixth and seventh day so all the cultures in lanes 5-10 were harvested simultaneously on day seven of the differentiation process.

The nitrocellulose blot was subsequently reacted with the monospecific anti-C/EBP and anti-LAP antisera. The 36-kD DNA-binding activity comigrated with the LAP immunoreactivity and the 42-kD DNA-binding activity comigrated with the C/EBP immunoreactivity. Analysis of the Western blots (Fig. 3, bottom two panels) shows that C/EBP and LAP immunoreactivity behave discordantly during differentiation and cytokine treatment, paralleling the DNA-binding activity of the respective proteins. We ascribe the apparent discrepancy between the dominant contribution of C/EBP to the DNA-binding complex of untreated adipocytes (as determined by the antiserum supershifting experiments, Fig. $2 c$, lane 2) and the relatively weak 42-kD signal on the Southwestern (Fig. 3, lane 5 ) to the fact that C/EBP forms homodimers relatively poorly

CREB
Figure 3. Inflammatory cytokines reverse the differentiation-dependent pattern of nuclear C/EBP-like proteins in adipocytes. $(A)$ Aliquots of nuclear protein from 3T3 $\mathrm{L} 1$ cells $(80 \mu \mathrm{g})$, harvested at various time points during the differentiation process (lanes 1-5), and after conditioned medium treatment (lanes 6-10), were analyzed by Southwestern blot using labeled APRE M6 as a probe (upper panel). The positions of C/EBP and LAP are indicated by the arrows to the left of the autoradiograph. Lane 11 contains bacterially expressed C/EBP as a positive control. The blot was subsequently reacted with anti-C/EBP antisera (middle panel) and anti-LAP antisera (lower panel) in a Western immunoblot.

C/EBP
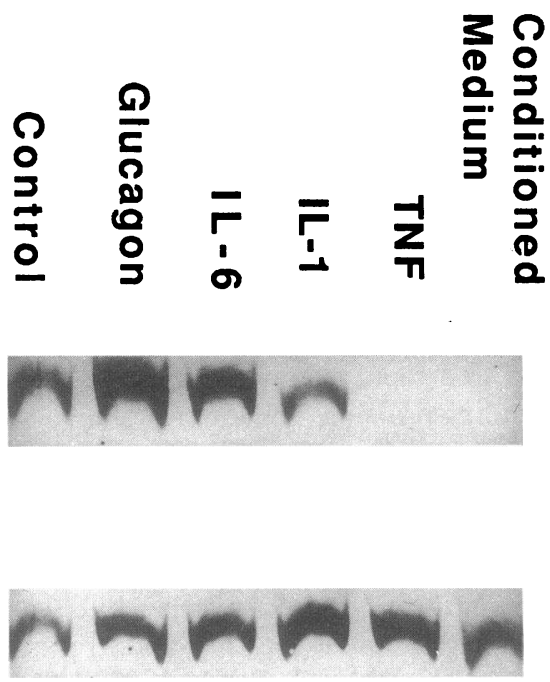

Figure 4. Western blot analysis of C/EBP immunoreactivity in nuclear extracts of adipocytes treated with various cytokines. Identical plates of differentiated 3T3-L1 cells were treated with the indicated cytokines for a period of 24 hours before extraction of nuclear proteins and sequential Western immunoblot analysis with anti-C/EBP antisera (top panel) and, as an internal control, anti-CREB antisera (bottom panel). Concentration of cytokines used: Glucagon, $1 \mathrm{nM}$; human recombinant interleukin-6 (IL-6), $200 \mathrm{U} / \mathrm{ml}$; human recombinant interleukin- $1 \alpha(I L-1), 100 \mathrm{U} / \mathrm{ml}$; human recombinant tumor necrosis factor- $\alpha(T N F), 50 \mathrm{ng} / \mathrm{ml}$; LPS-treated Raw 264.7 monocytic cell-conditioned medium (conditioned medium), $0.5 \% \mathrm{vol} / \mathrm{vol}$. 
(unpublished observations). DNA binding in Southwestern depends on homodimerization and is therefore weak, whereas in the antibody supershifting experiments heteromeric configurations of $\mathrm{C} / \mathrm{EBP}$ will also be detected and they are abundant in untreated cells (Fig. $2 c$ ). The results of the Western blot allow us to conclude that the reduction in C/EBP DNA-binding activity and increase in LAP DNA-binding activity that occur after cytokine treatment of adipocytes, noted in both the EMSA and Southwestern blot, is due to a specific reduction in quantity of nuclear C/EBP protein and an increase in LAP protein.

To determine which of the cytokines present in the monocyte-conditioned medium accounts for the decrease in C/EBP immunoreactivity, day seven adipocytes were treated with pure preparations of recombinant cytokines expressed in $E$. coli. Western immunoblots of nuclear extracts of the treated cells were reacted with anti-C/EBP antisera. 24 hours of treatment with human TNF- $\alpha(50 \mathrm{ng} / \mathrm{ml})$ or the monocyte-conditioned medium $(0.5 \% \mathrm{vol} / \mathrm{vol})$ led to a specific decrease in the C/EBP immunoreactivity. Human interleukin- $1 \alpha(100 \mathrm{U} / \mathrm{ml})$ had a similar but less pronounced effect. Human interleukin-6 (200 $\mathrm{U} / \mathrm{ml}$ ) and the peptide glucagon $(1 \mathrm{nM})$ did not lead to a decrease in C/EBP immunoreactivity (Fig. 4). The structurally related transcription factor CREB (cAMP response element binding protein) served as an invariant positive control in these assays. We conclude that TNF is the cytokine predominantly responsible for the decrease in $\mathrm{C} / \mathrm{EBP}$ levels in adipocyte nuclei induced by the conditioned medium.

To follow the intracellular fate of C/EBP during cytokine treatment of the adipocytic cells we performed immunocytochemical analysis of C/EBP immunoreactivity. Fully differentiated adipocytes contain abundant $\mathrm{C} / \mathrm{EBP}$ which is localized exclusively to the nucleus (Fig. 5). This is consistent with the observations that in liver parenchymal cells C/EBP is a nuclear protein (13). Treatment with monocyte-conditioned medium led to a time dependent decrease in nuclear C/EBP immunoreactivity. This reduction was not associated with the accumulation of the immunoreactivity in any other cellular compartment, suggesting that once C/EBP leaves the nucleus it is rapidly degraded. 24 hours of treatment with $50 \mathrm{ng} / \mathrm{ml}$ recombinant human TNF $\alpha$ also caused a reduction in C/EBP nuclear immunoreactivity.

$C / E B P$ turns over rapidly in adipocytes and cytokines decrease its rate of synthesis. To investigate the mechanism underlying the cytokine-induced decrease in C/EBP immunoreactivity we evaluated the metabolic half-life of the protein and its rate of synthesis under normal conditions and following cytokine treatment of the cells. Pulse-chase labeling of adipocytes followed by specific immunoprecipitation of C/EBP demonstrates that $\mathrm{C} / \mathrm{EBP}$ is a labile cellular constituent with a half-life of less than two hours (Fig. 6, lanes 4-6). The metabolic fate of
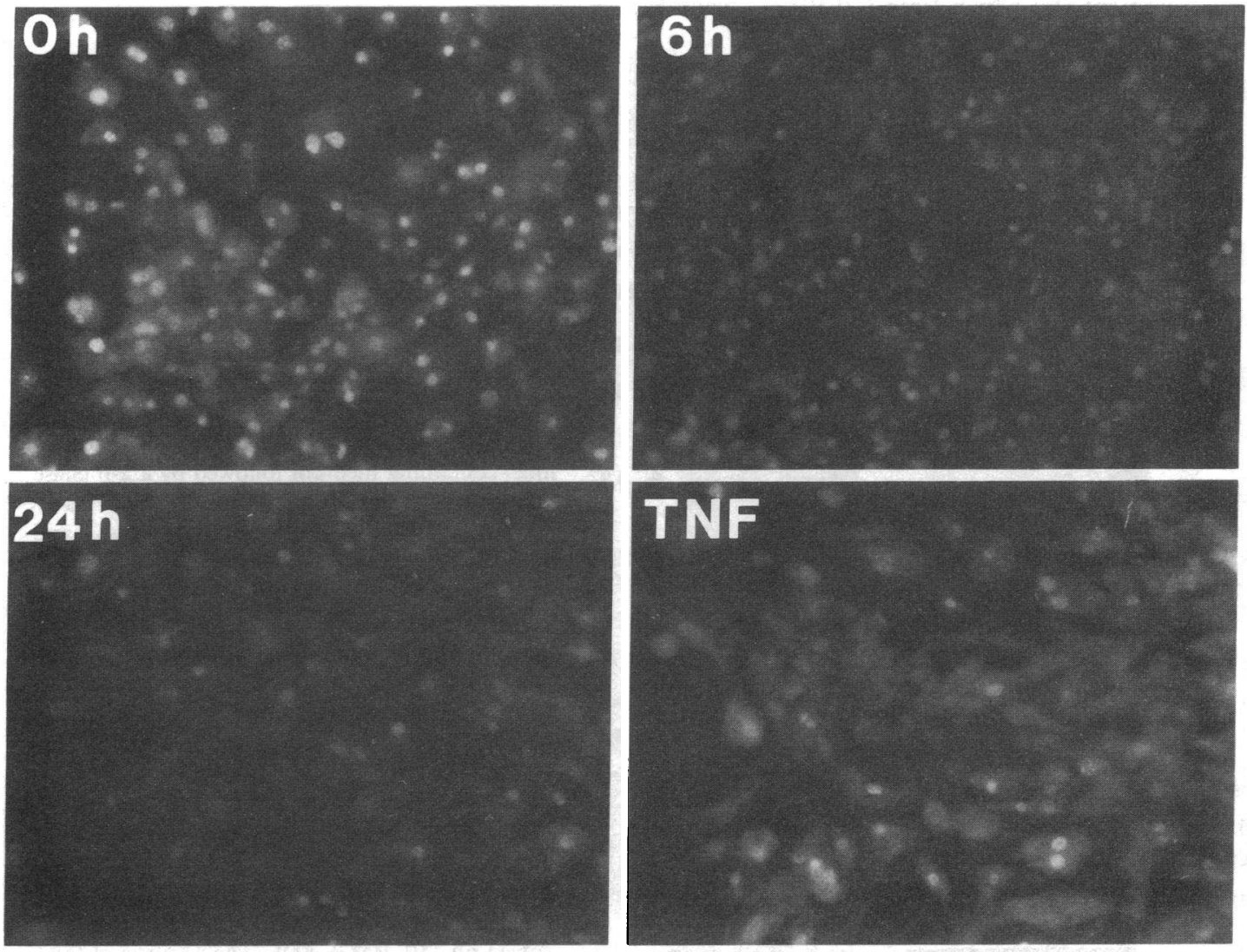

Figure 5. Immunohistochemical localization of C/EBP in cytokine-treated adipocytes. 3T3-L1 cells cultured on cover slides were induced to differentiate to adipocytes. $0.5 \% \mathrm{vol} / \mathrm{vol}$ conditioned medium or human TNF $\alpha 50 \mathrm{ng} / \mathrm{ml}$ was added to identically differentiated cells. After 6 hours or 24 hours ( 24 hours only, for the TNF $\alpha$-treated cells) the cells were fixed, reacted with anti-C/EBP antisera, and stained with a fluorescein-conjugated second antibody. The panel shows photomicrographs of the cells under fluorescent light. The round white spots on the dark background are the immunostained nuclei of the adipocytes. 
preformed $\mathrm{C} / \mathrm{EBP}$ is not significantly affected by cytokine treatment of the cells during the chase period (Fig. 6, lanes 4, 7, and 8 ). On the other hand treatment of the adipocytes with cytokines, before metabolic labeling led to a significant, time dependent decrease in C/EBP synthesis (Fig. 6, lanes 9-12). The specificity of the decrease in the synthesis rate of C/EBP is attested to by the lack of any measurable effect of cytokine treatment on the synthesis of CREB (precipitated from the $\mathrm{C}$ / EBP immunoprecipitate supernatants with a specific antiserum to CREB) or the intensity of the prominent "nonspecific" bands that are coprecipitated by the C/EBP antiserum. The short half-life of C/EBP noted in the adipocytes is in marked contrast to the relatively long half-life of C/EBP when expressed in Cos 1 cells. It is likely that lability of the preformed protein is a prerequisite for the cytokine-induced fall in C/EBP levels because such a cytokine-induced fall in C/EBP was not seen in the transfected Cos 1 cells (data not shown).

Cytokine-induced decrease in $C / E B P$ synthesis is due to a decrease in $m R N A$ levels that occurs without a decrease in $C /$ $E B P$ gene transcription. Cytokine treatment of adipocytes is associated with a progressive decrease in C/EBP mRNA levels as determined by Northern blot analysis (Fig. $7 \mathrm{~A}$ ). The decrease appears to account for some of the time dependent fall in synthesis rate of the protein, with decreased mRNA levels occurring within three hours of cytokine treatment. Interestingly, the fall in C/EBP mRNA levels does not appear to be due to a decrease in transcription of the C/EBP gene, because nuclear run-on analysis demonstrates sustained levels of transcription four hours after cytokine treatment (by which time C/EBP
mRNA levels had decreased by almost twofold, Fig. 7 B). It would thus appear that in adipocytes inflammatory cytokines cause an early decrease in C/EBP levels in part through an mRNA destabilizing effect.

\section{Discussion}

In this study we provide evidence for the association of a cell culture model of the inflammatory state (refered to as the acute phase) with a reciprocal change in the ambient nuclear levels of two transcriptional regulatory proteins, C/EBP and LAP. These two DNA-binding proteins have been shown to bind indistinguishably to a variety of regulatory sequences important in modulating the expression of genes during the acute phase (Fig. 1 and 21-23). We demonstrate here that in cultured adipocytes treated with cytokines, C/EBP and LAP levels reciprocally decrease and increase, respectively.

The decrease in C/EBP DNA-binding activity and immunoreactivity is a specific response to the action of the inflammatory cytokines TNF, and, to a lesser degree, IL-1. This appears to be an early event in cytokine action; a decrease in the rate of $\mathrm{C} / \mathrm{EBP}$ synthesis is detected within one hour of the addition of monocyte conditioned medium to cultured adipocytes (Fig. 6, lane 10). This rapid response is consistent with the possibility that the cytokine-induced change in C/EBP levels may play a role in mediating some of the effects of cytokines on gene transcription, rather than being a late consequence of a cytokineinduced change in the cellular phenotype, a process that takes place over several days.

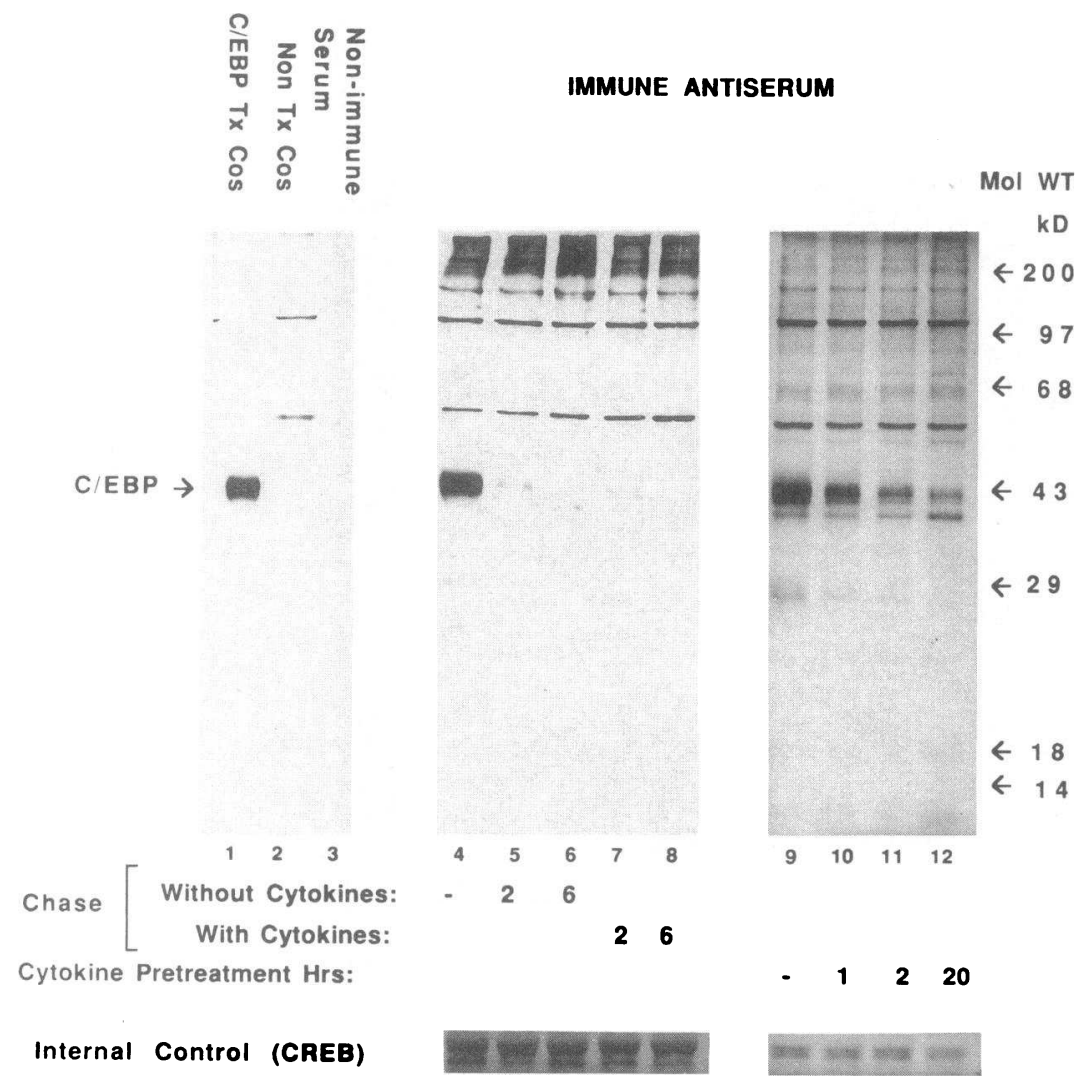

Figure 6. Analysis of the effect of inflammatory cytokines on the in vivo half-life and synthesis rate of C/EBP. Specificity of the immunoprecipitation procedure (left panel): Immunoprecipitation with anti-C/EBP antiserum of ${ }^{35} \mathrm{~S}$-labeled nuclear proteins from Cos 1 cells transfected with a C/EBP expression vector (lane 1 ) or a control vector with the insert in the reverse orientation (lane 2). The equivalent of $1 / 10$ of the material loaded onto lane 2 was loaded onto lane 1 , hence the faintness of the background bands. Estimation of C/EBP half-life and synthesis rate (middle and right panels): 3T3-L1 adipocytes were labeled for $1.5 \mathrm{~h}$ in ${ }^{35} \mathrm{~S}$-methionine-containing medium followed by a 2 -h chase incubation with medium containing unlabeled methionine (lanes 5 and 7) or a 6-h chase (lanes 6 and 8 ), in the absence of conditioned medium (lanes 5 and 6 ) or in its presence (lanes 7 and 8 ). The cells in lanes 3 and 4 were harvested immediately after labeling. The material in lane 3 was immunoprecipitated using nonimmune serum whereas lanes 4-12 were immunoprecipitated with anti-C/EBP antiserum. The effect of cytokine treatment on C/EBP synthesis (lanes 9-12) was estimated by pretreating the cells with conditioned medium for the specified period of time before and during the labeling procedure. Labeled proteins in the nuclear extracts were subsequently immunoprecipitated without a chase incubation period. The labeled proteins were resolved on $11 \%$ PAGE-SDS. The position of the $\mathrm{C} /$ EBP immunoreactive material is indicated by the arrow to the left of the autoradiograph. The supernatants of the C/EBP immunoprecipitation procedure were further immunoprecipitated with anti-CREB antisera as an internal recovery marker. The CREB immunoprecipitate is displayed in the bottom panel. 


\section{Conditioned \\ a Medium, hours: \\ $\begin{array}{llll}0 & 3 & 6 & 24\end{array}$}

C/EBP

LAP

\section{$\rightarrow$}
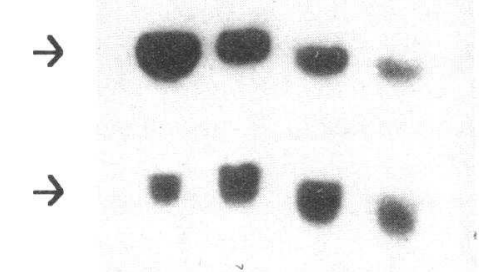

\section{ACTIN}
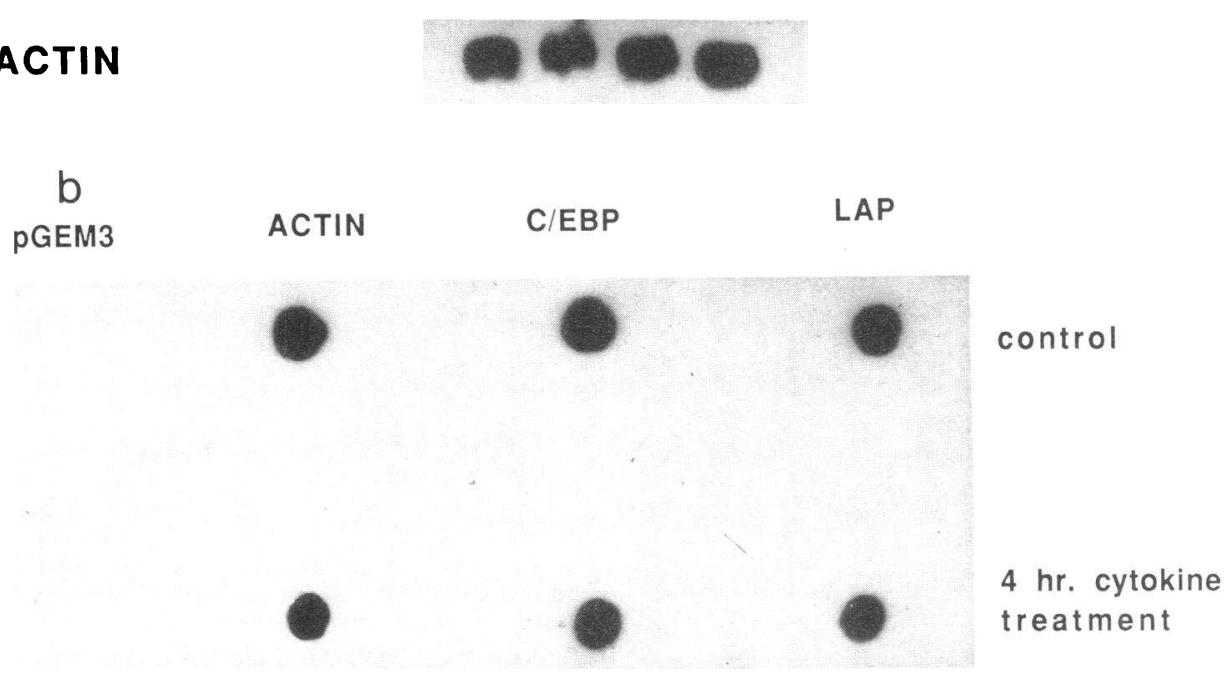

Figure 7. Effect of inflammatory cytokines on C/EBP and LAP mRNA levels and gene transcription rate. (A) $20 \mu \mathrm{g}$ total cellular RNA from adipocytes treated for the indicated time with conditioned medium were fractionated on $1.2 \%$ agarose gels and analyzed by Northern blot. Labeled C/EBP and LAP cDNAs were used as the hybridization probes in the upper panel and actin as an internal control in the lower panel. $(B)$ Isolated nuclei, from identical plates of 3T3-L1 adipocytes cultured in the absence (control) or presence of conditioned medium (4 hr. cytokine treatment), were incubated in the presence of ${ }^{32} \mathrm{P}$-labeled UTP. Labeled mRNA species were hybridized to nitrocellulose filters containing an excess of the indicated nucleic acid sequence. After extensive washing of the nonhybridizing mRNA species (X0.1SSC at $65^{\circ} \mathrm{C}$ ) the filters were exposed to autoradiography.

The physiological mechanism that underlies the cytokineinduced decrease in C/EBP levels is a specific reduction in the synthesis rate of the protein. Based on the observation that C/EBP (in the adipocyte cell culture model) has a very short half-life, the decrease in the synthesis of C/EBP indeed would be expected to result in a rapid fall in ambient protein levels. This chain of events is consistent with a role for C/EBP in transducing some of the effects of TNF and IL-1 to alterations in gene transcription.

The decreased synthesis of C/EBP during cytokine treatment correlates with a decrease in mRNA levels, which in turn does not appear to be associated with a decreased rate of C/EBP gene transcription. This result suggests that cytokine-induced destabilization of the mRNA may contribute to the reduced synthesis of C/EBP.

One consequence of the acute phase-induced alteration in the abundance of C/EBP-like proteins is to change the ratio of
C/EBP and LAP in the nucleus and as a consequence the composition of the complex that forms at the C/EBP-binding site of various promoters. $\mathrm{C} / \mathrm{EBP}$ and LAP are very similar in the primary amino acid sequence of their carboxy-terminal DNAbinding and dimerization domains. The two proteins heterodimerize readily and bind the same DNA sequences (20-23). It seems likely therefore that the ratio of C/EBP to LAP in nuclear extracts, as measured in the in vitro binding assays, is proportional to the contribution of the two proteins to the complex that assembles on regulatory elements of genes in vivo. What might therefore be the significance of the cytokineinduced alteration in this ratio?

Outside the DNA-binding domain the amino acid sequences of LAP and C/EBP diverge considerably. The significance of this divergence in terms of protein structure is emphasized, for example, by the fact that polyclonal antisera directed against one protein fail to react with the other. In spite of this 
dissimilarity in the presumed "effector regions" of the molecules (35), previous studies have failed to uncover a qualitative difference between the two proteins: both activate promoters containing multiple C/EBP-binding sites, although LAP alone is consistently less effective than $\mathrm{C} / \mathrm{EBP}$ alone $(20,22)$. Our finding that the cytokine-induced alteration in C/EBP and LAP is associated with an early increase in the activity of a C/EBP-binding site-driven promoter is consistent with data suggesting that the ratio of these two transcription factors plays an important role in transcriptional activation. This appears to be true for artificial reporter genes driven by multiple C/EBPbinding sites (22, and our unpublished observations).

The reasons for the discrepancy between the behavior of the endogenous angiotensinogen mRNA (which is decreased after 24 hours of cytokine treatment, Fig. 1 b) and the activity of the transfected C/EBP-binding site-containing reporter plasmid (which is increased shortly after cytokine treatment, Fig. $2 d$ ) are not known. However, adipocyte differentiation-dependent induction of angiotensinogen $\mathrm{mRNA}$ is dependent on the activity of promoter elements other than the C/EBP-binding APRE (McGhee, R. E., Jr., et al., unpublished data). It follows therefore that cytokine treatment of 3T3-L1 adipocytes may affect angiotensinogen gene expression by developmental mechanisms unrelated to changes in levels of C/EBP-like proteins.

One appealing hypothesis is that replacement of C/EBP by LAP during the acute phase may also account for some of the decrease in transcriptional activity of genes, such as the albumin gene that is negatively regulated by inflammatory cytokines $(39,40)$. This hypothesis assigns a role to the cytokine-induced changes in the C/EBP-LAP ratio in determining the expression of those genes whose products are important in defining the metabolic profile of tissues such as adipose and liver (see 17). Treatment of animals with cytokines, shown by us to affect the C/EBP-LAP ratio, is associated with marked changes in the metabolism of fat, carbohydrate, and protein culminating in the induction of a syndrome of cachexia $(8,40)$. One would have to explain how the acute phase-induced change in the C/EBP-LAP ratio negatively affects the expression of some genes (e.g., albumin, 40) and positively affects the expression of others (e.g., haptoglobin, 22). Promoter-specific interactions with other transcription factors may provide part of the explanation. For example, the organization and function of the angiotensinogen gene is such that variations in the ability of the C/EBP-like complex that binds the APRE to interact with the adjacently bound glucocorticoid receptor, would be predicted to have a marked effect on promoter activity $(25,27)$.

The physiological significance of the cytokine-induced alterations in $\mathrm{C} / \mathrm{EBP}$-like proteins that occur with cytokine treatment may not be restricted to a direct effect on promoter activity. One possibility suggested by our observations on differentiating 3T3-L1 cells is that LAP may be an important $\mathrm{C} / \mathrm{EBP}$-like transcription activating protein in dividing cells, whereas C/EBP may serve the same function in terminally differentiated cells. In differentiating 3T3-L1 cells, LAP levels are maximal at a time when the cells are undergoing the last two rounds of replication, before attaining the quiescent phase (41). It is upon quiescence that C/EBP levels rise and LAP diminishes. It has been reported that a ligand-dependent conditional mutant of $\mathrm{C} / \mathrm{EBP}$ is capable of inhibiting the replication of DNA in proliferating 3T3-L1 cells (19). The paucity of C/EBP immunoreactivity in continuously dividing cells (42) is also consistent with an incompatibility between expression of $\mathrm{C}$ / EBP and cellular division. These observations suggest that the purpose for the cytokine induced change in the levels of $C / E B P$ and LAP may be to provide C/EBP-like activating proteins in conditions in which a nonproliferating differentiated cell is preparing itself for the possibility of renewed replication. This occurrence may represent either an adaptive response to the tissue injury, commonly encountered during those perturbations that give rise to the secretion of TNF and IL-1, or as an evolutionary atavism, a vestige of times in which differentiated tissues retained a greater capacity for reparative proliferation. The observation that $\mathrm{C} / \mathrm{EBP}$ levels fall during the liver regeneration that follows carbon tetrachloride poisoning is consistent with this notion (43). Understanding the significance of the cytokine-induced change in $\mathrm{C} / \mathrm{EBP}$-like proteins will await further characterization of the complex that assembles on C/EBPbinding sites in promoters of relevant genes as well as a definition of the role of other proteins that interact with C/EBP.

\section{Acknowledgments}

We thank the following people for contributing unique reagents that made this work possible: Steven L. McKnight and Alan D. Friedman (anti-C/EBP antiserum, and cDNA-containing vectors); Ricardo Cortese and Dipak Ramji (anti-IL-6DBP antiserum and cDNA-containing vectors); Shizuo Akira and Tadamitsu Kishimoto (NFIL-6 cDNA); Patrick Descombes and Ueli Schibler (LAP bacterial expression vector); Steve Gillis (recombinant IL-1). We also thank Kathryn A. Wright for expert technical assistance, Townly Budde for secretarial assistance, and Heather Hermann for special assistance.

The studies were supported in part by U. S. Public Health Service grants DK 25532 and DK 30457.

\section{References}

1. Foster, D. W. 1991. Gain and loss in weight. In Principles of Internal Medicine. 12th ed. J. D. Wilson, E. Braunwald, K. J. Isselbacher, R. G. Petersdorf, J. B. Martin, A. S. Fauci, and R. K. Root, editors. McGraw-Hill Inc., New York. 259-261.

2. Beutler, B., J. Mahoney, N. Le Trang, P. Pekela, and A. Cerami. 1985. Purification of cachectin, a lipoprotein lipase-suppressing hormone secreted by endotoxin-induced RAW264.7 cells. J. Exp. Med. 161:984-995.

3. Silva, C. L., and N. T. Foss. 1989. Tumor necrosis factor in leprosy patients. J. Infect. Dis. 159:787-790.

4. Scuderi, P., K. E. Sterling, K. S. Lam, P. R. Finley, K. J. Ryan, C. G. Ray, E. Petersen, D. J. Slymen, and S. E. Salmon. 1986. Raised serum level of tumor necrosis factor in parasitic infections. Lancet. ii:1364-1365.

5. Balkwill, F., R. Osborne, F. Burke, S. Naylor, D. Talbot, H. Durbin, J. Tavernier, and W. Fiers. 1987. Evidence for tumor necrosis factor/cachectin production in cancer. Lancet. ii:1229-1232.

6. Lahdevirta, J., C. P. J. Maury, A.-M. Teppo, and H. Repo. 1988. Elevated levels of circulating cachectin/tumor necrosis factor in patients with acquired immunodeficiency syndrome. Am. J. Med. 85:289-291.

7. Levine, B., J. Kalman, L. Mayer, H. M. Fillit, and M. Packer. 1990. Elevated circulating levels of tumor necrosis factor in severe chronic heart failure. $N$. Engl. J. Med. 323:236-241.

8. Oliff, A., D. Defeo-Jones, M. Boyer, D. Martinez, D. Kiefer, G. Vuocolo, A. Wolfe, and S. H. Socher. 1987. Tumors secreting human TNF/Cachectin induce cachexia in mice. Cell. 50:555-563.

9. Torti, F. M., B. Dieckmann, B. Beutler, A. Cerami, and G. M. Ringold. 1985. A macrophage factor inhibits adipocyte gene expression: an in-vitro model of cachexia. Science (Wash. DC). 229:867-869.

10. Kawakami, M., and A. Cerami. 1981. Studies of endotoxin-induced decrease in lipoprotein lipase activity. J. Exp. Med. 154:631-639.

11. Pekala, P. H., M. Kawakami, C. W. Angus, M. D. Lane, and A. Cerami. 1983. Selective inhibition of synthesis of enzymes for de- novo fatty acid biosynthesis by an endotoxin-induced mediator from exudate cells. Proc. Natl. Acad. Sci. USA. 80:2743-2747.

12. Ringold, G. M., A. B. Chapman, D. M. Knight, M. Navre, and F. M. 
Torti. 1988. Hormonal control of adipocyte differentiation and adipocyte gene expression. Recent Prog. Horm. Res. 44:115-140.

13. Birkenmeier, E. H., B. Gwyenn, S. Howard, J. Jerry, J. I. Gordon, W. H. Landschultz, and S. L. McKnight. 1989. Tissue-specific expression, developmental regulation, and genetic mapping of the gene encoding CCAAT/enhancer binding protein. Genes Dev. 3:1146-1156.

14. Christy, R. J., V. W. Yang, J. M. Ntambi, D. E. Geiman, W. H. Landschultz, A. D. Friedman, Y. Nakabeppu, T. J. Kelly, and M. D. Lane. 1989. Differentiation-induced gene expression in 3T3-L1 preadipocytes: CCAAT/enhancer binding protein interacts with and activates the promoters of two adipocyte-specific genes. Genes Dev. 3:1323-1335.

15. Kaestner, K. H., R. J. Christy, and M. D. Lane. 1990. Mouse insulin-responsive glucose transporter gene: characterization of the gene and transactivation by the CCAAT/enhancer binding protein. Proc. Natl. Acad. Sci. USA. 87:251-255.

16. Herrera, R., S. R. Hyo, G. R. Robinson, K. G. Xanthopoulos, and B. M. Spiegelman. 1989. A direct role for C/EBP and the AP-1 binding site in gene expression linked to adipocyte differentiation. Mol. Cell. Biol. 9:5331-5339.

17. McKnight, S. L., M. D. Lane, and S. Gluecksohn-Waelsch. 1989. Is CCAAT/enhancer-binding protein a central regulator of energy metabolism? Genes Dev. 3:2021-2024.

18. Saye, J. A., L. A. Casis, T. W. Sturgill, K. R. Lynch, and M. J. Peach. 1989. Angiotensinogen gene expression in 3T3-Ll cells. Am. J. Physiol. 256:C448C451.

19. Umek, R. M., A. D. Friedman, and S. L. McKnight. 1991. CCAAT-enhancer binding protein: a component of a differentiation switch. Science (Wash. DC). 251:288-292.

20. Descombes, P., M. Chojkier, S., Lichtsteiner, E. Falvey, and U. Schibler. 1990. LAP, a novel member of the C/EBP gene family, encodes a liver-enriched transcriptional activator protein. Genes \& Dev. 4:1541-1551.

21. Akira, S., H. Isshiki, T. Sugita, O. Tanabe, S., Kinoshita, Y. Nishio, T. Nakajima, T. Hirano, and T. Kishimoto. 1990. A nuclear factor for IL-6 expression (NFIL-6) is a member of the C/EBP family. EMBO (Eur. Mol. Biol. Organ.) J. 9:1897-1906.

22. Poli, P., F. P. Mancini, and R. Cortese. 1990. IL-6DBP, a nuclear protein involved in interleukin-6 signal transduction, defines a new family of leucine zipper proteins related to C/EBP. Cell. 63:643-653.

23. Chang, C.-J., T.-T. Chen, H.-Y. Lei, D.-S. Chen, and S.-C. Lee. 1990. Molecular cloning of a transcription factor, AGP/EBP, that belongs to members of the C/EBP family. Mol. Cell. Biol. 10:6642-6653.

24. Ron, D., A. R. Brasier, K. W. Wright, J. E. Tate, and J. F. Habener. 1990. An inducible 50-kilodalton $\mathrm{NF} \kappa \mathrm{B}$-like protein and a constitutive protein both bind the acute-phase response element of the angiotensinogen gene. Mol. Cell. Biol. 10:1023-1032.

25. Ron, D., A. R. Brasier, K. W. Wright, and J. F. Habener. 1990. The permissive role of glucocorticoids on IL-1 stimulation of angiotensinogen gene transcription is mediated by an interaction between inducible enhancers. $\mathrm{Mol}$. Cell. Biol. 10:4389-4395.

26. Brasier, A. R., D. Ron, J. E. Tate, and J. F. Habener. 1990. Synergistic enhansons, located within an acute phase responsive enhancer, modulate glucocorticoid induction of angiotensinogen gene transcription. Mol. Endocrinol. 4:1923-1933.
27. Brasier, A. R., D. Ron, J. E. Tate, and J. F. Habener. 1990. A family of constitutive C/EBP-like DNA-binding proteins attenuate the IL-lalpha-induced, $\mathrm{NF} \kappa \mathrm{B}$-mediated transactivation of the angiotensinogen acute-phase response element. EMBO (Eur. Mol. Biol. Organ.) J. 9:3933-3944.

28. Landschultz, W. H., P. F. Johnson, E. Y. Adashi, B. J. Graves, and S. L. McKnight. 1988. Isolation of a recombinant copy of the gene encoding C/EBP Genes \& Dev. 2:786-800.

29. Studier, F. W., A. H. Rosenberg, J. J. Dunn, and J. W. Dubendorff. 1990. Use of T7 RNA polymerase to direct the expression of cloned genes, Methods Enzymol. 185:60-89.

30. Brasier, A. R., J. E. Tate, D. Ron, and J. F. Habener. 1989. Multiple cis-acting DNA regulatory elements mediate hepatic angiotensinogen gene expression. Mol. Endocrinol. 3:1022-1034.

31. Weiss, G. H., O. M. Rosen, and C. S. Rubin. 1980. Regulation of fatty acid synthetase concentration and activity during adipocyte differentiation. J. Biol. Chem. 255:4751-4757.

32. Schreiber, E., P. Matthias, M. M. Muller, and W. Schaffner. 1989. Rapid detection of octamer binding proteins with "mini-extracts", prepared from a small number of cells. Nucleic Acids Res. 17:6419.

33. Hoeffler, J. P., T. E. Meyer, Y. Yun, J. L. Jameson, and J. F. Habener. 1988. Cyclic AMP-response element DNA-binding protein: structure based on a cloned placental cDNA. Science (Wash. DC). 242:1430-1433.

34. Lee, C. Q., Y. Yun, J. P. Hoeffler, and J. F. Habener. 1990. Cyclic-AMPresponsive transcriptional activation of CREB-327 involves interdependent phosphorylated subdomains. EMBO (Eur. Mol. Biol. Organ.) J. 9:4455-4465.

35. Friedman, A. D., and S. L. McKnight. 1990. Identification of two polypeptide segments of CCAAT/enhancer-binding protein required for transcriptional activation of the serum albumin gene. Genes \& Dev. 4:1416-1426.

36. Harlow, E., and D. Lane. 1988. Antibodies-A Laboratory Manual. Cold Spring Harbor Laboratory, Cold Spring Harbor, NY.

37. Greenberg, M. E. Identification of newly transcribed RNA. 1987. In Current Protocols in Molecular Biology. F. M. Ausbel, R. Brent, R. E. Kingston, D. D. Moore, J. A. Smith, J. D. Seidman, and K. Struhl, editors. Wiley Interscience, New York.

38. Spiegelman, B. M., M. Frank, and H. Green. 1983. Molecular cloning of mRNA from 3T3 adipocytes. J. Biol. Chem. 258:10083-10089.

39. Birch, H. E., and G. Schreiber. 1986. Transcriptional regulation of plasma protein synthesis during inflammation. J. Biol. Chem. 261:8077-8080.

40. Brenner, D. A., M. Buck, S. P., Feitelberg, and M. Chojkier. 1990. Tumor necrosis factor inhibits albumin gene expression in a murine model of cachexia. $J$. Clin. Invest. 85:248-255.

41. Schmidt, W., G. Poll-Jordan, and G. Loffler. 1990. Adipose conversion of 3T3-L1 cells in a serum-free culture system depends on epidermal growth factor, insulin-like growth factor-I, corticosterone, and cyclic AMP. J. Biol. Chem. 265:15489-15495.

42. Friedman, A. D., W. H. Landscultz, and S. L. McKnight. 1989. CCAAT/ enhancer binding protein activates the promoter of the serum albumin gene in cultured hepatoma cells. Genes \& Dev. 3:1314-1322.

43. Xanthopoulos, K. G. J. Mirkovitch, T. Decker, C. K. Kuo, and J. E. Darnell. 1989. Cell-specific transcriptional control of the mouse DNA-binding protein mC/EMP. Proc. Natl. Acad. Sci. USA. 86:4117-4121. 